\title{
Stakeholder value judgments in decision-making on the incorporation, financing, and allocation of new health technologies in limited-resource settings: a potential Brazilian approach
}

\author{
Luiz Santoro Neto, ${ }^{1}$ Fernanda Lessa, ${ }^{1}$ Elene Paltrinieri Nardi, ${ }^{1}$ and Marcos Bosi Ferraz ${ }^{1}$
}

Suggested citation

Santoro Neto L, Lessa F, Nardi EP, Ferraz MB. Stakeholder value judgments in decision-making on the incorporation, financing, and allocation of new health technologies in limited-resource settings: a potential Brazilian approach. Rev Panam Salud Publica. 2018;42:e102. https://doi.org/10.26633/RPSP.2018.102

ABSTRACT Objective. To analyze the value judgments behind cost-benefit tradeoffs made by health stakeholders in deciding whether or not to incorporate new health technologies and how they should be financed and allocated in limited-resource settings in Brazil.

Method. From June 2009 to January 2010, a sample of stakeholders in the public and private health sector was identified and invited to complete an online survey consisting of two questionnaires: one collecting socio-demographic/professional information and one capturing resource allocation preferences in four hypothetical scenarios for the incorporation of new health technologies. Results. A total of 193 respondents completed the survey; more than half were male $(53.9 \%)$ and the most common age group was 31-40 years (36.8\%). Scenario 1 (incorporation of a new drug treatment for chronic disease, by reducing/eliminating resources for existing programs) was rejected by $49.2 \%$ of the survey sample, who preferred to maintain the status quo for existing programs. Scenario 2 (incorporation of the same new treatment, but financed by a new tax) was rejected by $58.0 \%$. Scenario 3 (incorporation of a new treatment for a highly lethal disease, by age group - 20-75 years versus 75+ years - by reducing/eliminating resources for existing programs), was rejected by $42.0 \%$, while $20.7 \%$ supported allocations for both groups, $34.2 \%$ supported allocations exclusively for the 20-75-year age group, and 3.1\% supported allocations exclusively for the $75+$ year age group. For Scenario 4, which consisted of five different resource allocations for prevention and treatment programs for another highly lethal disease, the most preferred option (chosen by $50.8 \%$ of respondents) was $75 \%: 25 \%$ (prevention versus treatment).

Conclusions. When incorporating a new health technology requires reducing/eliminating other health programs, financing it through a tax, or having to choose certain age groups (e.g., younger, working people versus older people), respondents are likely to reject it. When offered the choice of limiting the scope of the program (e.g., prevention versus treatment), respondents are likely to favor prevention. This was the first study in Brazil to capture value judgments that affect stakeholder decision-making on various resource allocations for different scenarios for health technology introduction in limited-resource settings. Future research should investigate the perspective of society as a whole to determine the best approach for decision-making based on common values and consensus within a particular health care system.

Keywords Technology assessment, biomedical; decision making; decision making, organizational; judgment; Brazil. 
Brazil has a public and universal health system that ensures full access to health services for the entire resident population, the Unified Health System (Sistema Único de Saúde, SUS). In addition to the public system, there is a private health care system, which includes insurance and health plans. The incorporation of new health technologies takes place separately in Brazil's public and private health systems.

The SUS health technology incorporation process was established in 2006 with the creation of the Commission for Incorporation of Technologies (Comissão de Incorporação de Tecnologias, CITEC) $(1,2)$. In 2011, CITEC was replaced by the National Commission of Incorporation of Technology (Comissão Nacional de Incorporação de Tecnologias no SUS, CONITEC), which is responsible for advising the Brazilian Ministry of Health on decisions related to the incorporation, exclusion, or modification of health technologies in the SUS $(3,4)$.

The current decision-making process for incorporating new technologies in the public health care system involves several different stakeholders, including the Ministry of Health, the National Health Surveillance Agency (Agência Nacional de Vigilância Sanitária or ANVISA), universities, and the general population and Brazilian society as a whole (represented by health councils), among others $(4,5)$.

The National Regulatory Agency for Private Health Insurance and Plans (Agência Nacional de Saúde, ANS) is a regulator housed in the Ministry of Health that is in charge of regulating the health insurance system and establishing the List of Procedures for the health sectorthe mandatory minimum procedures (consultations, examinations, and treatments) that health plans must offer to their beneficiaries. The health insurance aspect of incorporating new health technologies is not well established, and it is unclear which stakeholders are involved in that part of the decision-making process $(6,7)$.

Decision-making on which technologies should be incorporated in the country's health system is extremely important, especially given the current budget restrictions in the health field, which have required more tradeoffs in terms of costs/benefits. In Brazil, total per capita spending on health is US\$ 1388 (purchase power parity, PPP), of which only $47.5 \%$ is from the public sector. This expenditure is less than Argentina's (US\$ 1550 PPP) and much lower than expenditure per capita in the United States (US\$ 8845 PPP), Canada (US\$ 4610 PPP), and the United Kingdom (US\$ 3235 PPP) (8).

Various alternatives have been identified for assessing the decision-making process for the incorporation of technologies in health systems, including conjoint and discrete choice studies, described elsewhere (9-13). These types of analysis were first applied in economic studies for the transportation sector, in the early 1980s, and, in the mid-1990s, in health economics $(9,11)$.

Due to the wide range in perceptions about the risks related to health interventions, and in values and preferences, individual stakeholders are being called on to contribute to collective health decisions (14). Little is known about these individuals' value judgments (criteria for making decisions) or the process that is used in decision-making related to the incorporation of health care technologies in Brazil. Therefore, in an attempt to understand how different stakeholders in the Brazilian health system would respond with regard to resource allocation decisions, this study explored the value judgments behind cost-benefit tradeoffs that are made in deciding whether or not to incorporate new health technologies and how they should be financed and allocated in limited-resource settings.

\section{MATERIALS AND METHODS}

This exploratory cross-sectional study was conducted between June 2009 and January 2010. The convenience sample of opinion leaders in the Brazilian health system consisted of the following groups: private health service providers; public health service providers; health insurance entities; the pharmaceutical industry; the Ministry of Health; regulatory agencies and health departments; clinical analysis, diagnostics, and radiology laboratories; universities and research centers; students from GRIDES (Interdepartmental Group of Health Economics, a research group at the Universidade Federal de São Paulo, UNIFESP); nongovernmental organizations (NGOs); trade unions; civil entities; and professional associations.
The sample was selected from a list of 707 professionals, compiled using contacts from GRIDES and by searching professional social networks such as LinkedIn.com and Platform Lattes, a Brazilian curricula database integration platform maintained by the federal bureau responsible for funding science and technology, Conselho Nacional de Desenvolvimento Científico e Tecnológico (CNPq). The following inclusion criteria were applied: participants had to have been active in their profession for at least six months and be directly or indirectly associated with activity related to the process of incorporating health technologies in Brazil. Teachers from UNIFESP were excluded from the sample.

All prospective study participants were asked to complete the survey in an email with an attached cover letter that explained the study and included a login and individual password for accessing the web platform. A maximum of two follow-up emails were sent to those did not respond after 30 and 60 days respectively. If a respondent did not answer any of the three emails, he/she was dropped from the study.

The research tool (survey) included two questionnaires: one collecting respondents' socioeconomic, demographic, and education data (e.g., university graduation date), plus information on their role in the health sector (specific area of activity, hierarchical level, sector (public versus private, or both), and macroregion of operation), and one collecting data on their preferred resource allocations for four hypothetical scenarios involving the incorporation of new health technologies in the Brazilian health system. All scenarios were developed and described to replicate the current situation in Brazil, including budget constraints and the inability to fully meet all service demands in the health sector (i.e., the need for tradeoffs). The four scenarios are described below.

Scenario 1: Incorporation of a new drug treatment for chronic disease by reducing or eliminating resources for existing programs. This scenario consisted of a new drug that provided the same health benefit (better quality of life and increased life expectancy) for two different diseases: Disease A (chronic, with no other available treatment) and Disease B (chronic, and more prevalent 
than Disease A, but with other available treatments). The cost of incorporating the new drug to treat both diseases was 120000 Brazilian reals (R\$) per patient per year: $\mathrm{R} \$ 45.6$ million/year for Disease A $(0.07 \%$ of the public federal, state, and local health budget for 2010), and, due to its higher prevalence, $\mathrm{R} \$ 4.56$ billion/ year for Disease B (7.00\% of the 2010 budget). Survey respondents were advised that the annual budget (2010) was already allocated (committed), making incorporation of the new treatment impossible without eliminating/reducing resources for other, existing health programs, and asked to choose one of four resource allocation options: 1) incorporating the drug for treating both Disease A and Disease B (at a total cost of $7.07 \%$ of the health budget) and reducing/eliminating one or more health programs; 2) incorporating the drug for treating Disease A only $(0.07 \%$ of the budget) and reducing/eliminating one or more health programs; 3) incorporating the drug for treating Disease B only (7.00\% of the budget) and reducing/eliminating one or more health programs; or 4) no incorporation of the new drug for treating either disease and continuation of the status quo for all existing health programs.

Scenario 2: Incorporation of the same new drug treatment, but financed by a new tax. Respondents were asked to consider the same parameters described in Scenario 1, but with a different financing mechanism for the new drug treatment-a new national tax-that would allow for status quo resource allocation to existing programs. The four resource allocation options for this scenario were: 1) incorporating the new drug for treating both Disease A and Disease B (7.07\% of the budget) by implementing the new tax; 2) incorporating the new drug for treating Disease A only $(0.07 \%$ of the budget) by implementing the new tax; 3) incorporating the new drug for treating Disease B only $(7.00 \%$ of the budget) by implementing the new tax; or 4) no incorporation of the new drug for treating either disease and no new tax.

Scenario 3: Incorporation of a new drug treatment for a highly lethal disease, by age group (20-75 years versus $75+$ years), by reducing or eliminating resources for existing programs. Respondents were asked to consider incorporation of a new treatment for a highly lethal disease that affected all age groups and for which incidence increased with age. The new treatment was indicated for late-diagnosed cases and brought health gains equal to one year of life in perfect health. The risk of developing the disease had increased twentyfold in the last 50 years and would reach 1 in every 5000 people in the upcoming year. Compared to existing treatment, the new drug represented a cost increase of approximately $\mathrm{R} \$ 50000.00$ per year per patient, and if all patients were treated, would have a total cost of $\mathrm{R} \$ 1.9$ billion per year $(2.7 \%$ of the public federal, state, and local health budget for 2010). Respondents were asked to consider two groups of patients for potential treatment with the new drug-people 20-75 years old (i.e., those with higher potential labor productivity for society and more years of remaining life expectancy, versus older age groups) and people more than 75 years old (with lower labor productivity and fewer years of remaining life expectancy). As in the first scenario, the budget was already committed, and one or more health programs would have to be reduced or discontinued in order to incorporate the new drug. The four resource allocation options for this scenario were: 1) incorporating the new drug for treatment in both age groups; 2) incorporating the new drug for treatment only in those 20-75 years old; 3) incorporating the new drug for treatment only in those older than 75 years; 4) not incorporating the new drug for treatment in either/any age group.

Scenario 4: Budget allocation for prevention programs and treatment programs for another highly lethal disease. This scenario involved allocation of resources for prevention and treatment of a pathology with high prevalence (51 cases for 100000 women in 2010) that, when not treated, has a high lethality (35\% in five years). Costs were described for prevention and early detection/treatment (assuming the campaign would reach $75 \%$ of eligible patients) versus late treatment (treating all diagnosed cases). The prevention program has effectiveness close to $100 \%$ in early detections; early detection is made by clinical examination and imaging tests; and early treatment has a cure rate ranging from $45 \%$ to $65 \%$. In this scenario, prevention and treatment had the same budgetary impact-about $1 \%$ of the annual budget-and there was no means of generating new resources for the pathology. Survey respondents were asked to select one of the five following allocations of the available resources ( $1 \%$ of the budget) for prevention programs and treatment programs: 1) $0 \%$ prevention (screening/early treatment) and 100\% treatment (late diagnosis); 2) 25\% prevention (screening/early treatment) and $75 \%$ treatment (late-diagnosis); 3) 50\% prevention (screening/early treatment) and 50\% treatment (late-diagnosis); 4) $75 \%$ prevention (screening/early treatment) and 25\% treatment (late-diagnosis); and 5) $100 \%$ prevention (screening/ early treatment) and $0 \%$ treatment (late-diagnosis).

The study protocol was reviewed and approved by the Research Ethics Committee of UNIFESP's Paulista Medical School (Escola Paulista de Medicina, EPM), and all respondents provided their consent to participate in the research.

\section{RESULTS}

A total of 193 individuals completed the survey (a response rate of $27.3 \%$ ). Table 1 lists the survey respondents' socio-demographic characteristics. More than half were male $(53.9 \%)$, the most common age group was 31-40 years old (71 respondents or $36.8 \%$ ), and most were from Brazil's Southeast region (167 or $86.5 \%$ ). Table 2 provides details about the respondents' education and specific area/type of work. Most had an MD degree (94 or $48.7 \%$ ) and worked in a manager position ( 49 or $25.4 \%$ ). The proportion of respondents from other regions of the country was very low.

Most respondents said their main role in the health system was managerial (with or without a manager position per se) (90 or $46.6 \%)$, followed by "health service provider" (74 or $38.3 \%$ ). A large proportion said they worked in the private health sector (72 or $37.3 \%$ ) and had no connection to government entities (102 or $52.9 \%$ ). Slightly lower proportions of the respondents said they worked for a public health service provider (58 or $30.1 \%$ ) or at universities or research centers (53 or $27.5 \%$ ). The remaining respondents were distributed 
TABLE 1. Socio-demographic characteristics of stakeholder survey respondents $(n=193)$ in study on value judgments that affect decision-making on the incorporation of new health technologies, Brazil, 2009-1010

\begin{tabular}{lr}
\hline Characteristic & No. (\%) \\
\hline Gender & $104(53.9)$ \\
Male & $89(46.1)$ \\
Female & \\
Age group (years) & $22(11.4)$ \\
$\leq 30$ & $71(36.8)$ \\
$31-40$ & $61(31.6)$ \\
$41-50$ & $33(17.1)$ \\
$51-60$ & $5(2.6)$ \\
$61-70$ & $1(0.5)$ \\
$>70$ & \\
Region & $167(86.5)$ \\
Southeast & $13(6.7)$ \\
Midwest & $8(4.2)$ \\
Northeast & $4(2.1)$ \\
South & $1(0.5)$ \\
North & \\
\hline Source: Prepared by the authors based on the survey \\
results.
\end{tabular}

across several other categories, with those who worked in laboratories (clinical analysis, diagnostics, or radiology) representing the lowest proportion of the sample ( 9 or $4.7 \%$ ).

Responses about resource allocation decisions for the four hypothetical scenarios are described in Table 3. In Scenario 1, 49.2\% (95/193 respondents) chose not to incorporate the new drug in order to maintain the status quo for existing programs, while 50.8\% (98/193) said they would, in some cases, incorporate a new drug over existing programs. For resource allocation by disease, 56 or $29.0 \%$ of respondents chose to allocate resources for Disease $\mathrm{A}$, which had a lower prevalence and thus less budget impact compared to Disease B. In Scenario 2 (which had the same parameters as Scenario 1, but with a different source of financing - a new tax), a higher proportion of respondents (112 or 58.0\%) did not choose either allocation. Compared to Scenario 1, more respondents who chose to incorporate the new drug said they would do it for both diseases (35 or $18.1 \%$ ).

In Scenario 3, 81 or $42.0 \%$ of the respondents said they would not incorporate a new treatment for a highly lethal
TABLE 2. Educational/professional characteristics (academic background, level, main role in health system, sector, government liaison, specific area of work) of health stakeholder survey respondents $(n=193)$ in study on value judgments that affect decision-making on the incorporation of new health technologies, Brazil, 2009-1010

\begin{tabular}{|c|c|}
\hline Characteristic & No. $(\%)$ \\
\hline \multicolumn{2}{|l|}{ Academic background } \\
\hline Medicine & $94(48.7)$ \\
\hline Nursing & $21(10.9)$ \\
\hline Administration & $20(10.4)$ \\
\hline Pharmacy & $16(8.3)$ \\
\hline Economy & $7(3.6)$ \\
\hline Physical therapy & $5(2.6)$ \\
\hline Law & $4(2.1)$ \\
\hline Engineering & $4(2.1)$ \\
\hline Other & $30(15.5)$ \\
\hline \multicolumn{2}{|l|}{ Hierarchical level } \\
\hline President & $6(3.1)$ \\
\hline Director & $38(19.7)$ \\
\hline Manager & $49(25.4)$ \\
\hline Supervisor/coordinator & $40(20.7)$ \\
\hline Technical & $38(19.7)$ \\
\hline Other & $30(15.5)$ \\
\hline \multicolumn{2}{|l|}{ Main role in health system } \\
\hline Managerial & $90(46.6)$ \\
\hline Health service provision & $74(38.3)$ \\
\hline Research & $33(17.1)$ \\
\hline Teaching & $28(14.5)$ \\
\hline Support services & $23(11.9)$ \\
\hline Other & $8(4.2)$ \\
\hline \multicolumn{2}{|l|}{ Health sector } \\
\hline Private only & $72(37.3)$ \\
\hline Public only & $50(25.9)$ \\
\hline Both, but mainly public & $36(18.7)$ \\
\hline Both, but mainly private & $35(18.1)$ \\
\hline \multicolumn{2}{|l|}{ Government liaison work ${ }^{\mathrm{a}}$} \\
\hline None & $102(52.9)$ \\
\hline Municipal & $25(12.9)$ \\
\hline State & $27(14.0)$ \\
\hline Federal & $44(22.8)$ \\
\hline National agency & $5(2.6)$ \\
\hline \multicolumn{2}{|l|}{ Specific area of work } \\
\hline Private health service provider & $74(38.3)$ \\
\hline Public health service provider & $58(30.1)$ \\
\hline Insurance or health plans & $28(14.5)$ \\
\hline Pharmaceuticals & $28(14.5)$ \\
\hline Ministry of Health, regulatory agency, or health department & $31(16.1)$ \\
\hline Clinical analysis, diagnostics, or radiology laboratory & $9(4.7)$ \\
\hline University or research center & $53(27.5)$ \\
\hline GRIDES $^{b}$ student & $23(11.9)$ \\
\hline Nonprofit organization, union, or professional association & $22(11.4)$ \\
\hline
\end{tabular}

Source: Prepared by the authors based on the survey results.

a This question allowed multiple answers.

${ }^{\mathrm{b}}$ Grupo Interdepartamental de Economia da Saúde, Universidade Federal de São Paulo. 
TABLE 3. Health stakeholders' preferred resource allocations for four hypothetical scenarios involving the incorporation of new health technologies, based on survey results from a study on value judgments that affect stakeholder decision-making, Brazil, 2009-1010

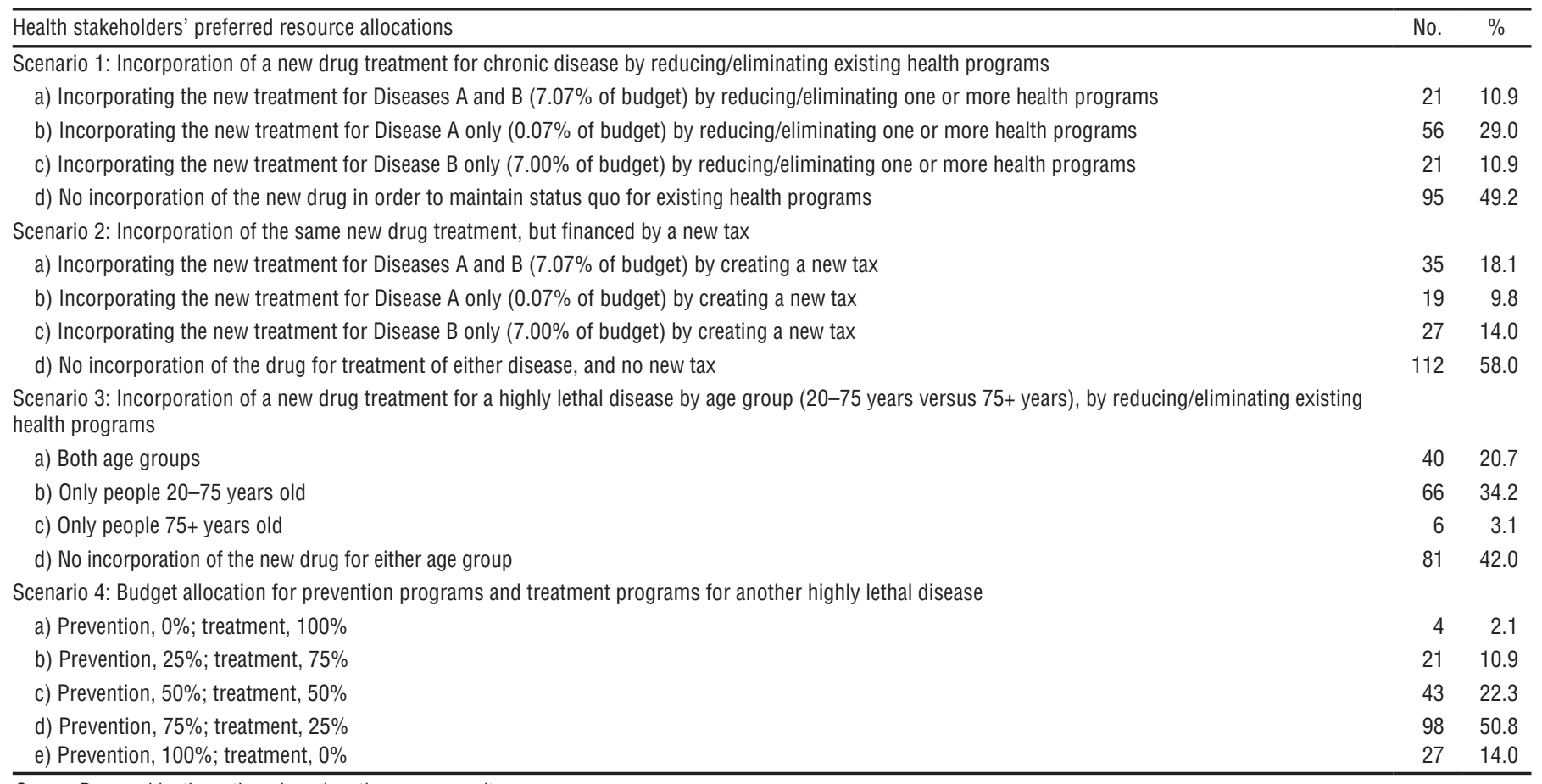

Source: Prepared by the authors based on the survey results.

disease that required reduction/elimination of other programs, for either of two age groups (20-75 or 75+ years), while 112 or $58.0 \%$ chose to incorporate it in some way. Among these, 66 or $34.2 \%$ said they would incorporate the new treatment only for those 20-75 years old, while 40 or $20.7 \%$ said they would do it for both age groups. Incorporation of the treatment exclusively for patients $75+$ years old was only chosen by 6 (3.1\%) of the respondents. In Scenario 4, 98 or $50.8 \%$ of the respondents opted to allocate resources for prevention programs and treatment programs for another highly lethal disease in a ratio of $75 \%$ to $25 \%$ respectively, while 43 or $22.3 \%$ chose to allocate resources for prevention and treatment at $50 \%$ each.

\section{DISCUSSION}

Understanding resource allocation decision-making for the incorporation of health technologies is important, especially given the current, limited resources in Brazil; the growth in health costs related to the introduction of new technologies in the market; the need for providing unlimited health services for an increasingly aging population; and the increasing judicial demands countries have been facing with regard to financing of new health technologies (15). By 2030, it is projected that the population will live an average of 78.6 years, almost 10 years longer than average lifetimes in 2000 (16). Currently, more and more individuals are being invited to contribute to decision-making on issues related to public health, bringing with them different values and preferences as well as different perceptions of the risks related to health interventions (14). The importance of identifying and understanding factors in decision-making on the allocation of health resources is even greater given the effect of the newest technologies, which may have a lower cost versus benefit in terms of their overall contribution to public health, although they are sometimes more expensive $(14,17,18)$. As health needs are expanding while resources to meet them become more restricted, allocation across different technologies becomes more and more important in maximizing benefits for the population $(10,19)$. Given the difficulty in understanding the determinants of individuals' decision-making for these types of allocations, this study explored how health care professionals, acting as stakeholders, express their preferences and values regarding the tradeoffs-implementing or not implementing various health care interventions, in specific scenarios- that become mandatory in an environment of absolute scarce resources.

In Scenario 1, the respondents were put into a hypothetical situation in which supporting the incorporation of a new drug in the health system would harm (reduce or eliminate resources for) existing health programs. Based on the information collected using this scenario, it was determined that if the new technology required a resource allocation that entailed reducing or eliminating resource for other health programs, many health professionals $(49.2 \%$, in this case) would not support its incorporation in the health system.

Of the 98 respondents who supported the incorporation of the technology, $56(29.0 \%)$ said they would only do so for Disease A, which required a smaller budget allocation $(0.07 \%)$ compared to Disease $B$, which would require $7.00 \%$ of the total health budget-a considerable amount given the current needs of the Brazilian public health system, and the constricted resources. In this context, the decision to incorporate the new treatment may have been due to the fact that there 
was no other available treatment for Disease A (as opposed to Disease B, which did have other treatments). This concurs with research by Green \& Gerard that assessed preferences in which the authors describe "availability of other treatments" as a relevant social value (12). However, the authors stressed that "improved health" and the "value of money" were the social values most strongly associated with the incorporation of new technologies into health systems (12).

Like Scenario 1, where respondents were concerned about the reduction or elimination of other health programs and a large proportion rejected the introduction of the new treatment altogether, the creation of a tax as an alternative financing method (Scenario 2) was not supported by most respondents-112 or $58 \%$ - an even higher proportion than Scenario 1. This result concurs with opinion polls that suggest Brazilians are against the creation of taxes to raise government revenue for health (20).

In the last 20 years, tax assessments on Brazilian citizens to fund specific health interventions have become more commonplace. From 1997 to 2007, through the Provisional Contribution on the Movement or Transmission of Securities and of Credits and Rights of a Financial Nature (Contribuição Provisória sobre a Movimentação ou Transmissão de Valores e de Créditos e Direitos de Natureza Financeira, CPMF), Brazilians paid a tax on general financial transactions of up to $0.38 \%$, with some of the revenue earmarked for public health, as well as social security and poverty eradication projects. Constitutional Amendment 29 (approved in 2000) linked the health revenue directly to states, municipalities, and the Federal Union, giving each entity a portion of the funds earmarked for the sector. However, the CPMF was eliminated in 2007, and attempts by the federal government to reinstate the tax have not been successful (21-23).

A new treatment for a highly lethal disease that also required reducing or eliminating resources for other health programs was described in Scenario 3, in which respondents had to allocate resources across two different age groups. Even though incidence of the disease increased with age and thus mainly affected the elderly, the most preferred option among those choosing any treatment allocation (with $42.0 \%$ choosing none) was to allot all resources for the 20-75-year age group (with only 3.1\% choosing to allocate all resources for the $75+$-year age group, and $20.7 \%$ choosing to cover both groups). This may reflect the value judgment that investing in a younger population with higher life expectancy is more efficient than investing in a population more than 75 years old (10). These results corroborate other studies that found a preference for allocating greater amounts for younger patients, and an aversion to allocating resources to patients with a shorter life expectancy or bad health/terminal conditions $(3,4)$. As in this study, respondents in another study were more willing to give greater or lesser priority to groups of patients with particular characteristics, suggesting that their decision on resource allocation was not based on the principles of equity in health (10). This type of response, and what it implies about stakeholder decision-making for resource allocation, becomes more important as populations age and life expectancy increases.

In Scenario 4, the decision involved the allocation of resources for prevention programs and treatment programs for another highly lethal disease. Respondents tended to opt for prevention more often than treatment. Greater preference for preventive interventions can be observed in work carried out in Belgium by Luyten et al. (24). The authors showed that prevention was preferred over treatment when the action was directed to young adults and involved a serious or fatal illness. The Belgian study also found the responses varied according to the age of respondents, and by lifestyle and state of health of the target population, but did not verify the factors that most influenced resource allocation decisions favoring prevention over treatment (24).

This study aimed to investigate, in a comprehensive manner, how respondents, acting as stakeholders of the Brazilian health system, would respond to various hypothetical situations, in a scenario of scarce resources. Thus, it provides important information regarding stakeholder value judgments and the decision-making process in determining the incorporation - or not-of health care technologies in specific scenarios in an environment of constricted budgetary resources. According to Silva \& Viana (5), the decision-making process for acquisition of new health technology in a selected set of service providers, and for specific health plans, is strongly influenced by both internal and external factors. Internal factors can include pressure from other staff, level or prestige of whoever is requesting the technology to be incorporated, availability of financial resources, and knowledge and familiarity with the technology; external factors may include competition between health service providers seeking greater competitiveness and market share, evidence-based information favoring the acquisition of safe and efficacious technology, and expected financial return associated with the acquisition of the health technology (5).

Scientific literature on the appraisal of value judgments in the process of assessing health technologies for incorporation into health systems is scarce. As the science develops, and methods for decreasing the uncertainty of decisions (typical of biological sciences) improve, along with life expectancy, and the quality of additional years of life lived, the assessment of individual and population value judgments affecting these decisions will become more important (14).

\section{Limitations}

As in any new study designed to shed light on specific and as yet unknown areas of knowledge, this study had some methodological limitations. One limitation is the relatively small sample, composed mostly of health care professionals, notably physicians, from the Southeast region of the country, who may not have been fully aware of the health technology assessment process and may have never actually participated in CITEC/ CONITEC decision-making processes. Another potential limitation is the study period, as the research was completed a few years ago. However, it seems doubtful that the scenarios presented in the survey, and the critical questions that were addressed, are of less importance or less valid nowadays. On the contrary, as time evolves, the relative scarcity of resources in the Brazilian health care system increases, and therefore the decision-making process, and the value judgments they reflect, become more important, along with the need for the best evidence available. Moreover, there is no reason to think that the value judgments expressed in this study have changed over this short period of time. For further analysis, however, the use of a larger and more comprehensive sample that incorporates and allows for 
evaluation of different types of professionals as stakeholders, and how they behave in resource allocation decisions based on different types of scenarioswhether they are consumers of technology (hospitals and clinics), payers (health departments, health plans), or suppliers of technology (pharmaceutical and medical devices) - is recommended. Another possible limitation was the broad nature of the different resource allocation scenarios studied. Collecting data on scenarios that are more specific would allow for more extensive investigation of one specific variable at a time (e.g., age of stakeholder, source of financing for the new treatment, type of treatment, etc.) and its influence on the value judgment of the decision-maker. Determining the value judgments of the patients who stand to benefit from the technology by involving them in the decision-making process might also be useful.

The use of a specially designed database as the source of survey respondents may also be a limitation by generating a sample that may not be representative of stakeholders nationwide. The database was designed to collect information about professionals engaged in the process of incorporating new health technologies, and a large portion of the sample $(46.6 \%)$ said they had a managerial role in the health care system. In addition, most of the sample was from the Southeast region $(86.5 \%)$. These potential limitations were not taken into account until after the data collection and analysis. The reason for the skewing of the sample toward the Southeast region remains unknown.

\section{Conclusions}

For three of the four scenarios described in the survey, a large proportion of respondents said they would choose not to incorporate the new health technology. Other findings included the following: 1) respondents seemed reluctant to incorporate a new health system treatment when it required reducing/eliminating other health programs or creating a new tax; 2) in the case of chronic disease, those who said they would incorporate a new treatment, even when it required reducing/eliminating other health programs, said they were most likely to do so when there was no other available treatment; 3) when a resource allocation option involved tradeoffs between different beneficiaries by age group, respondents tended to favor allocating the resources to younger people (of "productive" or working age) versus the elderly, even when the disease incidence increased with age; and 4) respondents tended to prefer allocating resources for prevention (screening and early detection/treatment) versus treatment for emerging cases with late diagnosis. These results may be useful for increasing recognition of the role of decision-makers' value judgments on the process of incorporating new health technologies.

Decisions about how, when, and whether to purchase and use new health technology should be based on highquality evidence on the impact of the new treatment on health care and health outcomes. Given the range in perceptions about the benefits and risks of health interventions, and in value sets and preferences, better understanding of the value judgments of decision-makers has a tremendous potential to transform the delivery of health care services and improve health outcomes. Within the context of increasing judicial demands related to the financing of health technologies, and the rapid development of new technologies, it is important to determine the value judgments that are made by stakeholders in deciding on which products and services to offer in a health system. This was the first study conducted in Brazil that captured stakeholders' value judgments with regard to different scenarios for health technology incorporation, in settings with scarce resources. Future work should investigate which stakeholder decisions about incorporating new health technologies into the health system are considered most appropriate by the general population-society as a whole - based on societal values and consensus.

Acknowledgments. The authors thank all those who agreed to participate in this study, and gratefully acknowledge the substantial improvement of the text made by the peer reviewers, and the critical role of the journal technical editors.

\section{Conflicts of interest. None.}

Disclaimer. Authors hold sole responsibility for the views expressed in the manuscript, which may not necessarily reflect the opinion or policy of the RPSP/ PAJPH or the Pan American Health Organization (PAHO).

\section{REFERENCES}

1. Wang DW. Avaliação de tecnologias em saúde: evidência clínica, análise econômica e análise de decisão [book review]. Rev Direito Sanit. 2011;12(2):318-24. doi: 10.11606/issn.2316-9044.v12i2p318-324.

2. Polanczyk CA, Vanni T, Kuchenbecker RS. Avaliação de tecnologias em saúde no Brasil e no contexto internacional. In: Nita ME, Secoli SR, Nobre MR, Ono-Nita SK, Campino AC, Sarti FM, et al. Avaliação de tecnologias em saúde: evidência clínica, análise econômica e análise de decisão. Porto Alegre: Artmed; 2010. Pp. 433-49.

3. Government of Brazil. Lei $n^{\circ} 12.401$, de 28 de abril de 2011. Altera a Lei no 8.080, de 19 de setembro de 1990, para dispor sobre a assistência terapêutica e a incorporação de tecnologia em saúde no âmbito do
Sistema Único de Saúde - SUS.; 28 de abril de 2011.

4. Capucho HC, Ribeiro FC, Vidal AT, Louly PG, Canuto Santos VC, Petramale CA. Incorporação de tecnologias em saúde no Brasil: novo modelo para o Sistema Único de Saúde. 2012;13(3):1215-22. Available from: http:/ / periodicos.ses.sp.bvs.br/pdf/ bis/v13n3/v13n3a03.pdf

5. Silva HP, Viana AL. Health technology diffusion in developing countries: a case study of CT scanners in Brazil. Health Policy Plan. 2011;26(5):385-94. doi: 10.1093/ heapol/czq076.

6. Departamento de Ciência e Tecnologia, Secretaria de Ciência e Tecnologia e Insumos Estratégicos, Ministério da Saúde. Avaliação de Tecnologias em Saúde: institucionalização das ações no
Ministério da Saúde. Rev Saude Publica. 2006;40(4). doi:10.1590/S0034-89102006000 500029.

7. Novais HM, Elias FT. Uso da avaliação de tecnologias em saúde em processos de análise para incorporação de tecnologias no Sistema Único de Saúde no Ministério da Saúde. Cad Saude Publica. 2013;29 Suppl 1:S7-16. doi: 10.1590/0102-311X00008413.

8. World Health Organization. World health statistics 2015. Geneva: WHO; 2015. Available from: http://www.who.int/gho/publications/world_health_statistics/2015/en/

9. Zweifel P, Breyer F, Kifmann M. Economic valuation of life and health. In: Zweifel $\mathrm{P}$, Breyer F, Kifmann M. Health economics. Berlin: Springer-Verlag; 2009.

10. Skedgel C, Wailoo A, Akehurst R. Societal preferences for distributive justice in 
the allocation of health care resources: a latent class discrete choice experiment. Med Decis Making. 2015;35(1):94-105. doi: 10.1177/0272989X14547915.

11. Howard K, Jan S, Rose JM, Wong G, Irving $\mathrm{M}$, Tong $\mathrm{A}$, et al. Community preferences for the allocation of donor organs for transplantation: a discrete choice study. Transplantation. 2015;99(3):560-7. doi: 10. 1097/TP.0000000000000365.

12. Green C, Gerard K. Exploring the social value of health-care interventions: a stated preference discrete choice experiment. Health Econ. 2009;18(8):951-76. doi: 10. 1002/hec.1414.

13. Kolasa K, Lewandowski T. Does it matter whose opinion we seek regarding the allocation of healthcare resources? A case study. BMC Health Serv Res. 2015;15(1):564. doi: 10.1186/s12913-015-1210-8.

14. Ferraz MB. Health care: the challenge to deal with uncertainty and value judgment. Cost Eff Resour Alloc. 2015;1(13):8. doi: 10.1186/s12962-015-0035-y.

15. Pinzón-Flórez CE, Chapman E, Cubillos L, Reveiz L. Prioritization of strategies to approach the judicialization of health in Latin America and the Caribbean. Rev Saude Publica. 2016;50:56. doi: 10.1590/ S1518-8787.2016050005728.
16. Instituto Brasileiro de Geografia e Estatística. Projeções da população, Brasil e Unidades da Federação. Série relatórios metodológicos. vol. 40. Rio de Janeiro: IBGE; 2013. 41 pp. Available from: ftp:// ftp.ibge.gov.br/Projecao_da_Populacao/ Projecao_da_Populacao_2013/srm40_ projecao_da_populacao.pdf

17. Goyen M, Debatin JF. Healthcare costs for new technologies. Eur J Nucl Med Mol Imaging. 2009;36 Suppl 1:S139-43. doi: $10.1007 /$ s00259-008-0975-y.

18. Gava CM, Bermudez JA, Pepe VL, dos Reis AL. Novos medicamentos registrados no Brasil: podem ser considerados como avanço terapêutico? Cien Saude Colet. 2010;15 Suppl 3:3403-12. doi: 10.1590/ S1413-81232010000900015.

19. Ferraz MB. Dilemmas and choices in healthcare: let's avoid taking the Ferrari off-road! Sao Paulo Med J. 2009;127(1): 5-6. doi: 10.1590/S1516-318020090001 00002.

20. Tomazelli I. Para $70 \%$ dos brasileiros, CPMF é "injusta", diz CNI/Ibope [news release]. 12 Jul. Rio de Janeiro: Abril Mídia SA; 2016. Available from: https://exame. abril.com.br/economia / para-70-dosbrasileiros-cpmf-e-injusta-diz-pesquisacni-ibope/
21. Senado Federal (BR). CPMF [Internet] Brasília: Senado; 2013. Available from: https://www12.senado.leg.br/noticias/ entenda-o-assunto/cpmf

22. Machado CV, Lima LD, Baptista TWF. Políticas de saúde no Brasil em tempos contraditórios: caminhos e tropeços na construção de um sistema universal. Cad Saude Publica. 2017;33 Suppl 2: e00129616. doi: 10.1590/0102-311x00129616.

23. França JR, Costa NR. A dinâmica da vinculação de recursos para a saúde no Brasil: 1995 a 2004. Cienc Saude Coletiva. 16(1): 241-57. doi: 10.1590/S1413-81232011000 100027.

24. Luyten J, Kessels R, Goos P, Beutels P. Public preferences for prioritizing preventive and curative health care interventions: a discrete choice experiment. Value Health. 2015;18(2):224-33. doi: 10.1016/j.jval.2014. 12.007 .

Manuscript submitted 13 December 2016. Revised version accepted for publication on 28 November 2017. 
RESUMEN

Juicios de valor de los interesados directos al tomar decisiones sobre la incorporación, el financiamiento y la asignación de nuevas tecnologías sanitarias en los entornos con recursos limitados: un posible enfoque para Brasil

Palabras clave
Objetivo. Analizar los juicios de valor que subyacen las concesiones en términos de costo-beneficio que hacen los interesados directos en materia de salud al decidir si se incorporan nuevas tecnologías sanitarias y cómo deben financiarse y asignarse en los entornos con recursos limitados en Brasil.

Método. De junio del 2009 a enero del 2010, se estableció una muestra de interesados directos en el sector público y privado de la salud y se los invitó a responder a una encuesta en línea que constaba de dos cuestionarios: uno que recopilaba información sociodemográfica y profesional, y otro que recogía las preferencias respecto a la asignación de recursos en cuatro situaciones hipotéticas para la incorporación de un nuevo tratamiento farmacológico.

Resultados. En total, 193 personas respondieron la encuesta; más de la mitad eran hombres (53,9\%) y el grupo etario más común fue de 31 a 40 años (36,8\%). La situación 1 (incorporación de un nuevo tratamiento farmacológico mediante reducción o eliminación de los recursos para programas existentes) fue rechazada por $49,2 \%$ de la muestra de la encuesta, que prefirió que se mantuviera el statu quo para los programas existentes. La situación 2 (incorporación de un tratamiento nuevo, financiada por un nuevo impuesto) fue rechazada por 58,0\%. La situación 3 (incorporación de un tratamiento nuevo por grupo etario, a saber, de 20 a 75 años frente a mayores de 75 años) fue rechazada por $42,0 \%$, mientras que $34,2 \%$ apoyó la asignación exclusivamente para el grupo de 20 a 75 años y 3,1\% apoyó la asignación exclusivamente para el grupo de mayores de 75 años. En cuanto a la situación 4, consistente en cinco asignaciones diferentes de recursos para un nuevo tratamiento farmacológico, la opción más preferida (elegida por $50,8 \%$ de los encuestados) fue de $75 \%$ a favor de la prevención y $25 \%$ a favor del tratamiento.

Conclusiones. Cuando la incorporación de una nueva tecnología sanitaria requiere reducir o eliminar otros programas de salud, financiarla mediante un impuesto o tener que elegir a ciertos grupos etarios (por ejemplo, personas más jóvenes que trabajan frente a personas mayores), es probable que los encuestados la rechacen. Cuando se ofrece la opción de limitar el alcance del programa (por ejemplo, prevención frente a tratamiento), es probable que los encuestados favorezcan la prevención. Este fue el primer estudio en Brasil que ha recogido los juicios de valor que influyen en la toma de decisiones por los interesados directos sobre diversas asignaciones de recursos para diferentes situaciones de introducción de tecnologías sanitarias en los entornos con recursos limitados. Las investigaciones futuras deben indagar la perspectiva de la sociedad en su conjunto para determinar el mejor enfoque para la toma de decisiones basada en los valores comunes y el consenso dentro de un sistema de atención de salud particular.

Evaluación de la tecnología biomédica; toma de decisiones; toma de decisiones en la organización; juicio; Brasil. 
RESUMO

\section{Apreciação valorativa dos interessados diretos na tomada de decisão sobre incorporação, custeio e alocação de novas tecnologias em saúde em cenários com recursos limitados: uma perspectiva em potencial para o Brasil}

Objetivo. Analisar a apreciação valorativa oculta nos trade-offs de custo-benefício feitas pelos interessados diretos da saúde ao decidirem se serão incorporados novos tratamentos medicamentosos e como eles serão custeados e alocados em cenários com recursos limitados no Brasil.

Métodos. De junho de 2009 a janeiro de 2010, uma amostra de interessados diretos do setor público-privado da saúde foi identificada e convidada a responder uma pesquisa online compreendendo dois questionários: o primeiro para coleta de dados sociodemográficos/profissionais e o segundo para conhecer as preferências de alocação de recursos com a incorporação de um novo tratamento medicamentoso em quatro cenários hipotéticos.

Resultados. Ao todo, 193 participantes responderam a pesquisa. Mais da metade da amostra era do sexo masculino (53,9\%) e pertencia à faixa etária de 31 a 40 anos $(36,8 \%)$. O cenário 1 (incorporação do novo tratamento medicamentoso com a redução ou a extinção de recursos para programas existentes) foi rejeitado por $49,2 \%$ da amostra estudada, que deram preferência a manter a situação corrente dos programas existentes. O cenário 2 (incorporação do novo tratamento custeado por um novo imposto) foi rejeitado por $58,0 \%$. O cenário 3 (incorporação do novo tratamento por faixa etária: 20 a 75 anos ou acima de 75 anos) foi rejeitado por $42,0 \%$, sendo que $34,2 \%$ apoiaram a alocação exclusiva para a faixa etária de 20 a 75 anos e 3,1\%, para a faixa acima de 75 anos. Quanto ao cenário 4, que compreendia cinco tipos de alocação de recursos para o novo tratamento medicamento, a opção de maior preferência (indicada por $50,8 \%$ dos participantes) foi uma razão de $75 \%$ a $25 \%$ (para prevenção e tratamento, respectivamente).

Conclusões. Quando a incorporação de uma nova tecnologia em saúde requeria a redução ou a extinção de outros programas de saúde, o custeio com a arrecadação tributária ou a escolha entre determinadas faixas etárias (por exemplo, população jovem, ativa ou idosa), os participantes tenderam a rejeitá-la. Quando eles tiveram a opção de restringir o alcance do programa (por exemplo, prevenção ou tratamento), verificou-se uma tendência a favor da prevenção. Trata-se do primeiro estudo realizado no Brasil para conhecer a apreciação valorativa que influencia a tomada de decisão dos interessados diretos em alocações variadas de recursos em diferentes situações para a introdução de tecnologia em saúde em cenários com recursos limitados. Outras pesquisas devem ser realizadas para investigar a perspectiva da sociedade como um todo a fim de se determinar a melhor perspectiva para a tomada de decisão fundada nos valores comuns e no consenso em um sistema de atenção de saúde em particular.

Palavras-chave

Avaliação da tecnologia biomédica; tomada de decisões; tomada de decisões gerenciais; julgamento; Brasil. 